\title{
Lontarak Literation Culture Among Students Through Local History Learning
}

\author{
Bahri* \\ Department of History Education, \\ Faculty of Social Science \\ Universitas Negeri Makassar \\ Makassar, Indonesia \\ bahri@unm.ac.id \\ Andi Dewi Riang Tati \\ Department of Elementary School \\ Education, \\ Faculty of Social Science \\ Universitas Negeri Makassar \\ Makassar, Indonesia \\ andi.dewi.riang@unm.ac.id
}

\author{
Asmunandar \\ Department of History Education, \\ Faculty of Social Science \\ Universitas Negeri Makassar \\ Makassar, Indonesia \\ asmunandar@unm.ac \\ Misnah \\ Faculity of Teacher Training \\ and Education \\ Universitas Tadulako \\ Palu, Indonesia \\ misnah@untad.ac.id
}

\author{
Khaeruddin \\ Department of History Education, \\ Faculty of Social Science \\ Universitas Negeri Makassar \\ Makassar, Indonesia \\ khaeruddin@unm.ac.id
}

\begin{abstract}
Literacy efforts to increase empathy for south Sulawesi's rich history and culture. Lontarak is a learning resource containing local historical material of South Sulawesi that has not been integrated into learning. Students as a younger generation should be able to identify, find reconstruct and appreciate the various historical events recorded in the country. The purpose of this research is to develop a culture of literacy lontarak in local history learning for students of the History Education Study Program of Makassar State University. This study uses qualitative descriptive methods. The results found that the culture of literacy among students in the History Education Study Program of Makassar State University is related to 1) curriculum, 2) campus culture, 3) professionalism of lecturers and 4) interest in learning students towards lontarak as a source of learning local history.
\end{abstract}

\section{Keywords: Literacy, Lontarak and Local History}

\section{INTRODUCTION}

Lontarak is a historical and cultural heritage of Bugis Makassar community that has high value. Various philosophers and admonitions are found in lontarak. It was originally passed down orally, but in its development was expressed containing classical knowledge and spells. Lontarak refers to the understanding of writings, documents, books, letters and manuscripts. Other opinions define lontarak as a chronicle of a story written on lontarak leaves using a sharp tool. Learning lontarak is an effort to maintain locality and ancestral messages. In fact, studying historical history aims to: 1) gain an understanding of historical facts; 2) gain knowledge at a certain period in the people who live in the period in question; 3) gain fluency in evaluating and assessing historical works; 4) study related to historical research; 5) learn historiography [3]. Historical literacy is the ability to negotiate and make interpretations of the past by utilizing artifacts and documents as facts. Evidence is a means of building critical historical knowledge by weighing the function and usefulness of a fact, elaborating on the desire to assess and examine theories or opinions related to the past through a fact; and make facts to stimulate interest better with the past. Based on the interpretation of facts, students can get various perspectives so that they can realize that historical agents are people who have a tendency to varying points of view. Students who are able to identify different perspectives, also empathize and not only interpret the past with a single perspective, but also from another perspective based on the facts it obtains. Historical learning is an important part of educational activities that play a big role in making students human beings. The significance of historical knowledge is to help students in solving current problems. The predisposition to history is overrated as a lesson to live a better present life. The concept in consideration develops historical awareness defined as the awareness of the present past and the interconnection between the two. Within the framework this concept can be further defined as the talents and skills of students who need pedagogy to effectively develop it. This concept to realize a new approach to historical teaching still depends on the leap between theory and skill to ensure its application in the classroom. Local history can increase understanding of locality, instill a sense of identity into the community, and enable increased interest in studying cultural heritage.

\section{METHOD}

In this study, the method used is qualitative descriptive. Implemented in the Historical Education Study Program of Makassar State University. The subjects of the study were students of the class of 2018. The implementation of this research in the gasal semester of 2019. Information processing and data collection in preliminary research activities are carried out on three aspects, namely: 1) written sources that include; books, documents, books and other written sources. 2) person, by meeting and asking informants (lecturers and students). It can also be with 
interviews and and polls. 3) place, both silent and moving. Plece silenced his mass; facilities, objects, colors and more). While the place moves like; learning activities and more [10]. Supporting devices in data collection activities are also used in the development stage of effectiveness, among others; observation sheets, questionnaires and interview sheets. Activities on data analysis include: 1) data aggregation, 2) data reduction, 3) data feed, 4) verivikasi/conclusion [11].

\section{RESULTS AND DISCUSSION}

Based on the results of research related to the culture of literacy lontarak in students of the Historical Education Study Program of Makassar State University is influenced by several factors, including; 1) campus culture, 2) curriculum, 3) professionalism lecturer 4) student interest makes lontarak a reference to local history courses. From the results of interviews and observations, although the learning that lecturers have done is good, but does not use lontarak as a reference for learning. Lecturers as facilitators in learning only use modules as a reference for local history courses. The local history learning model used so far has not been able to give suggestions to students to get used to reading lontarak. The learning has not been able to realize students who love the local history of the area, the products of history and culture, including lontarak. Lecturers have also not been able to use the historical empathy potential of students. Lecturers do not use innovative learning resources in the classroom. Historical empathy students on lontarak, only up to inventory. The lecturer of local history courses said that the historical empathy of students towards lontarak is very minimal.

Makassar State University campus culture that supports the utilization of south Sulawesi's cultural potential in local history learning, in contrast to the use of lontarak as a reference for learning. Learning runs conventionally and uses limited references in the form of books and modules only. The culture of the campus has an impact on students' motivation towards literacy. Makassar and South Sulawesi in general that have various variants of history have not been able to evoke the literacy culture of lontarak students who are only fixated on certain references. Lecturers are also resistant to lectures and syllabuses of local history courses without being accompanied by innovative learning models.

Based on field obeservasi, the challenge of literacy in integrating in local history learning in students of the Historical Education Study Program of Makassar State University, caused by; 1) motivation in literacy among students is very low. 2) lecturers do not integrate local history learning into the noble values of Bugis Makassar that are widely included in lontarak. 3) limited students in reading lontarak that has not been transleted in Indonesian spelling.

The cultural approach to historical learning emphasizes the relationship between learning and human development in a social context. Historical learning in a cultural perspective has implications for classroom learning with the social, cultural, intellectual and political lives of students thus serving to realize sociocritical literacy towards students. Literacy culture is an educational activity that reduces the interactive and interdependent relationship between educational and intellectual institutions. The method of realizing the scientific tradition on the college's insitution by utilizing the culture of literacy among students.

To find out the historical empathy of students, researchers used interview and questionnaire methods. Based on the results of the interview, it is illustrated that the student is not able to express historical empathy, but from the answers from the questionnaire and interview found the dimensions of historical empathy of the student. The affective dimensions of students are explored when asked how they feel when using lontarak as a reference in local history learning. The expression of students is happy because the references are varied and innovative, some are amazed by the cultural results of their people in the past so it appears suggestive to know the site. When the question is related to the un treated lontarak or who has not been translate in Indonesian spelling. Answers vary, generally students disagree with the condition. Students are ified because the next generation can not see the culture of their nation and generally like if lontarak who each use the Bugis Makassar alphabet is translate in Indonesian (Ashari, Interview, September 16, 2019). From this experience, students have a contextual experience when reading lontarak as the local culture of Bugis Makassar community. Students can identify important events in an empire, including micro events. As stated by Ibrahim that by reading lontarak Sukkunna Wajo, I can know a lot about Wajo Kingdom, not only macro events but also micro events (interview, September 16, 2019). Another comment from Ikhsan that by reading lontarak, enriches the local historical resources of South Sulawesi (Interview, September 16, 2019). An interesting comment from Hariyanti that reading lontarak is a manifestation of our love for ancestral culture. Historical empathy of students towards lontarak, still limited inventory and documentation (Interview, September 17, 2019).

According to the lecturer of historical empathy skills students in literacy lontarak, still low. Historical empathy of students is not based on critical studies of various events that are included in lontarak and noble values that can be implemented in daily life. In realizing student historical empathy, the learning model used is one that can develop the construction of thinking analysis and develop affective abilities, such as courage to express opinions, analyze historical evidence as a relic of the past. The unrealization of historical empathy among students is due to several things, such as campus culture, lecturer factors that do not integrate values in local history learning, or interest from students towards local history learning (Amirullah, wawncara September 20, 2019). The results of research observations in the field show that the fact in the field of lecturers' efforts is very weak in utilizing the historical potential of emphathy students. Lecturers do not have the 
initiative to provide innovative learning resources in the classroom, including lontarak and other references such as pappaseng, kelong, royo, sinrilik, local history books that can support learning to be more meaningful. Lecturers only prioritize learning for pedagogical abilities without elaborating with innovative learning supported by the use of historical resources. This is illustrated from the comments of the students, every lecture conducted, did not find anything new including the reference used (Arsyad, Interview September 19, 2019). Observations and interviews to be described that although students use lontarak as a reference, but have not been able to study and analyze learning materials, generally students do not understand the content of lontarak (Amirullah, Interview September 20, 2019). Students argue that the material in the module is very limited, while the reference books only kasuistis discuss certain events only (Ikbal, Interview September 17, 2019).

The success of lontarak literacy culture in students of The History Education Study Program of Makassar State University depends heavily on the models and methods used by lecturers. Similarly, the resources and references used greatly influence students' interest in using lontarak as a reference for learning as well as in the preparation of final tasks. Paper assignments, both individual assignments and group assignments must be required to use lontarak as a reference. With literacy lontarak can reconstruct the disposition of student ness in which there are various character values that can be used as role models in life. Lecturers should always integrate the content of lontarak in learning, both in the initial activities of lectures, core activities and in closing activities. In the opening activity at the time the character values contained in lontarak are integrated in explaining the purpose of learning as well as in the activities of the perception. In the core activities, both in group discussions and when lecturers explain the material of integrating values in lontarak by making lontarak as a reference, for example when explaining related Wajo Kingdom, then lontarak sukunna Wajo is used, as well as when the material is related to bone kingdom then the reference used is Lontarak Bone. In the final stage, lecturers conduct evaluation stages by doing feedback while still making lontarak as a reference, lecturers can convey several messages in lontarak related to the theme of learning.

The results of interviews with lecturers say that the main obstacle in realizing the literacy culture of lontarak students is due to several factors, for example many students cannot read lontarak script, while many lontarak have not been translate in Indonesian spelling, other factors lontarak availability in the library is very limited. Lecturers revealed that students do not have lontarak references that can help realize lontarak literacy (Khaeruddin, interview September $12,2019)$. The inability of students to read lontarak script is unfortunate because the regional language subjects in elementary and junior high schools have learned the language of bugis-speaking makassar, even in these schools the teacher still uses the local language as an introductory language in learning activities as well as curricular extar activities. Lecturers also have not used various places as a learning resource that provides lontarak. Whereas almost all periodization of the local history of South Sulawesi, especially the period of the kingdom has lontarak. Although the local historical material is very good which refers to the syllabus and semister teaching plan (RPS), lontarak as a source of local history learning is not well used.

Integrating lontarak in learning, preferably not only on local history courses, but also other courses. The use of lontarak as a source of learning local history will support the realization of literacy culture among students. The Historical Education Study Program supports implementing lontarak as a source of local history learning in order to improve the literacy culture of lontarak students. The foundations of the literacy culture are; 1) mission vision of the Historical Education study program". 2) Law No. 20/2003; that the curriculum at all levels and types of education is developed with the principle of diversification in accordance with the unit of education, regional potential, and students. Supported by Law No. 22 of 1999, the local government and its ranks, and the community have the obligation and authority to manage and optimize the potential of the region. 3) The third aspect is the campus culture that develops and appreciates the potential of local culture in the vicinity.

\section{CONCLUSION}

The conclusion in this study is in realizing the culture of literacy among students need to consider several things, 1) curriculum, 2) campus culture, 3) professionalism of lecturers and 4) interest in learning students towards lontarak as a source of learning local history. The advice in the study expects other researchers interested in the same study to continue similar research so that it becomes a comparison material with this study. It is more daring to explore lontarak as a learning resource, not only on local history courses but also other courses.

\section{ACKNOWLEDGMENT}

Thank you very much to the Chancellor of the Universitas Negeri Makassar and the Dean of the UNM Faculty of Social Sciences who have provided funding and opportunities for us to conduct research, so that the writing from the results of this study can be completed.

\section{REFERENCES}

[1] A. D. R. T. Bahri, "Lontarak; Sumber Belajar Sejarah Lokal Sulawesi Selatan."

[2] A. Kartini, "Lontara Bilang sebagai Sumber Sejarah Kerajaan Gowa." Universitas Islam Negeri Alauddin Makassar, 2014.

[3] B. Garvey and M. Krug, "Model-Model Pembelajaran Sejarah di Sekolah Menengah,” Terjemahan. Yogyakarta: Ombak, 2015.

[4] S. M. Bennett, "Teachers' Beliefs and Implementation of Historical Literacy Pedagogy in Three Advanced Placement United States History Classrooms.," Georg. Soc. Stud. J., vol. 4, no. 2, pp. 53-67, 2014.

[5] C. Peck and P. Seixas, "Benchmarks of Historical Thinking: First Steps.," Can. J. Educ., vol. 31, no. 4, pp. 1015-1038, 2008.

[6] S. Wineburg, Berpikir historis: Memetakan Masa Depan, Mengajarkan Masa Lalu. Yayasan Obor Indonesia, 2006. 
[7] H. S. Hasan, "Kurikulum Pendidikan Sejarah Berbasis Kompetensi," in Makalah. Disampaikan dalam Seminar Nasional Ikatan Himpunan Mahasiswa Sejarah Se-Indonesia (IKAHIMSI). Universitas Negeri Semarang, Semarang, 2007, vol. 16.

[8] P. Roberts, "From Historical Literacy to a Pedagogy of History," Build. Bridg. Hist. Learn. Connect. Teach. Educ. museum Educ., 2011.

[9] B. Baco, T. Nuriah, and A. Idris, "Development of Local Historical Learning Resources South Sulawesi Based on Character Education in Department of Historical Education Faculty of Social Science at State University of Makassar,” Am. J. Educ. Res., vol. 6, no. 3, pp. 220-237, 2018.

[10]P. Alfrianti, "Peningkatan Kualitas Pembelajaran IPS Melalui Model Treffinger Berbantuan Media Powerpoint pada Siswa Kelas IV SDN Mangunsari Kota Semarang.” Universitas Negeri Semarang, 2014.

[11]Y. L. Loretta, "Nilai-Nilai Karakter Dalam Novel The Chronicle Of Kartini Karya Wiwid Prasetyo dan Penyusunannya Sebagai Bahan Ajar Sastra di SMA." Universitas Lampung, 2017.

[12]M. Pacheco and K. Gutiérrez, "Cultural-Historical Approaches to Literacy Teaching and Learning," Break. Silenc. Recognizing Soc. Cult. Resour. Students Bring to Classr., pp. 60-77, 2009.

[13] A. Azra, "Esai-esai Intelektual Muslim dan Pendidikan Islam, Tradisi dan Modernisme Menuju Milenium Baru," Jakarta Logos Wacana Ilmu, 1998.

[14] A. Surur, "Lektur Agama dalam Aksara Lontara Berbahasa Bugis," AlQalam, vol. 7, no. 2, pp. 24-30, 2018.

[15]E. Winaryati, "Model Evaluasi Nilai-Nilai Luhur (Menil) Pada Pembelajaran Sains, Berbasis Potensi Daerah: Suatu Pendekatan Model," 2012. 